\title{
Benchmarking Marketing and Business Strategy of UNIQLO to Start-up a Retail Shop in Bangladesh
}

\author{
Taposh Ranjan Sarker* Lefayet Sultan Lipol Abdullah Al Saeed \\ Department of Textile Engineering, Northern University Bangladesh, PO box 1229, \\ 111/2 Kawla Jamea Mosjid Road, Dakshin Khan (near Hazrat Shahjalal International Airport), Dhaka, \\ Bangladesh
}

\begin{abstract}
The aim of this study is to let an apparel business entrepreneur recognize the initiatives, challenges, channels, business and marketing strategy to start up a new apparel store. This investigation has been conducted by benchmarking marketing and business strategy of UNIQLO through BPM, SWOT Analysis and Porter's Five Forces Model in order to initiate a new retail shop. The BPM model scrutinizes the whole process of the organization like customer needs, management processes, core processes, support processes etc. in order to improve continuously. The whole process to build an apparel retail store as well as facilitate an entrepreneur to detect a way to establish an outstanding brand has been demonstrated by this model. Furthermore, a framework has been delivered by 'Marketing Mix' consisting of 4 elements: Product, Price, Place, Promotion to manage the market and cause it one into a business context. This research is a qualitative based study to explore the object in a reasonable manner. In this qualitative study, primary data are obtained through an interview with related respondents. Business goals, success factors, critical success factors, measurable process controls have been determined for the proposed apparel retail showroom. As sustainability plays a vital role to strengthen the brand image around the world, the probable means to generate it has also been conferred.
\end{abstract}

Keywords: BPM, location agnostic, apparels, retail-store, fitting room, omni-channel.

DOI: $10.7176 / \mathrm{EJBM} / 12-2-01$

Publication date: January $31^{\text {st }} 2020$

\section{Introduction}

To establish a retail shop there are many success factors that need to be checked and inspecting those factors business policies should be designed (Baker, J., Grewal, D. \& Levy, 1992). A business strategy is a plan to identify and satisfy the civil needs in order to attain the goal of a particular business entity. Additionally, fashion marketing is a process of making and selling apparel and accessories which attracts buyers, generally noted by 'Fashion Merchandising' that covers designing, developing, presenting for resale as well as promotions for selling (Wolfe, Mary, 2009). Market penetration requires an active relationship with customers through coordinated marketing (Kotler, P., Armstrong, G., Wong, V. \& Saunders, J., 2008). An understandable integrated marketing program will lead to an expeditious transmission of mission, value and message from the company to the target market. Therefore, marketing is everything that should be covered to associate an enterprise and its purchasers (University of California Riverside, 2010). Marketing Mix or 4Ps (Product, Price, Place and Promotion) are set of controllable activities of a company to response their target market's demand (Grewal and Levy, 2013). Fast fashion allows stores to constantly sell a high volume of clothes for competitive prices. In other words, dresses are made for immediate consumption, rather than for long-term wear. As a soon to be launched ready to wear apparel brand, UNIQLO provides daily men and women formal apparel. In the middle of tight competition, UNIQLO needs an effective marketing and business strategy to start up a new apparel retail store in Bangladesh.

\section{Research Description and Objective}

This analysis is qualitative based research. The paper identifies the required business development concept and marketing strategy specifically to commence a new apparel retail store in Bangladesh. Furthermore, analysis of BPM, lean retailing model, lean retailer supplier dynamics are conducted to continue the inquiry. Finally, findings of the investigation are illustrated through Marketing Mix, Porter's Five Forces Model and BPM analysis.

\subsection{Data Source}

In this report, we have gathered primary data. Data are received through consultation with concerned executives and available respondents, three consumers of direct competitors' brand (Infinity, Sailor, Aarong), one random online shopper, one fashion expert. Besides, conversation and group discussion were conducted to take expert point of view.

\subsection{Analysis Method}

The analysis method of this research is as follows:

i. Preparing assembled data in the form of interview transcripts from the respondents. 
ii. Coding the data and representing it in the form of narrative or qualitative documents according to the 4Ps aspect: product, price, place, and promotion.

Cross-checking the investigation result from a respondent to another respondent which will proceed to a pertinent marketing mix.

\section{Business Idea of Retail Clothing Shop}

3.1 Company Profile of UNIQLO

UNIQLO is a clothing apparel company, which was originally founded in Yamaguchi, Japan in 1949 as a textiles manufacturer. Now it is a global brand with over 1000 stores around the world. Founder of UNIQLO is Tadashi Yanai. Like H\&M, Zara, M\&S UNIQLO relies on the lucrative business model of fast fashion. Aside from designing its products, UNIQLO produces finished apparel through sourcing practice in order to give further job vacancies to local sewers, markets its product and deliver the goods to the shoppers itself. The vision of UNIQLO is to be the leading formal apparel brand for Bangladeshi men and women and the mission is to contribute to the development of local economy, precisely in the local production industry and creating job opportunities at the same time (White, Gillian B., 2019). There are many identical businesses that provide formal attire for men and women like UNIQLO in the local market, three remarkable competitors are Infinity, Cats-Eye and Aarong. To attain the number one position in the clothing business by providing fashionable, high-quality clothing products at the right price and on the right time to customers.

\subsection{Business goals}

i. $\quad$ Fill the store with fashionable wears and bring varieties in fashion and design for each season.

ii. Advertise to the target market as well as work on brand.

iii. Offer more to customers.

iv. Increasing profit 5-7\% annually.

v. Maintain a Green atmosphere by spending less power in retail wear shop.

\subsection{Lean Retailing}

In recent years, fashion attributes have infused nearly all garment types, product life cycles are shortening and product proliferation is accelerating even in the most basic garments. Increasing demand uncertainty has led to the advent of 'lean retailing' (Slaton, K., Testa, D., Bakhshian, S., Reid, S. and Fiore, A. M., 2018). The forces driving lean retailing are summarized in Figure 1 (F. Abernathy, J. Dunlop, 1999).

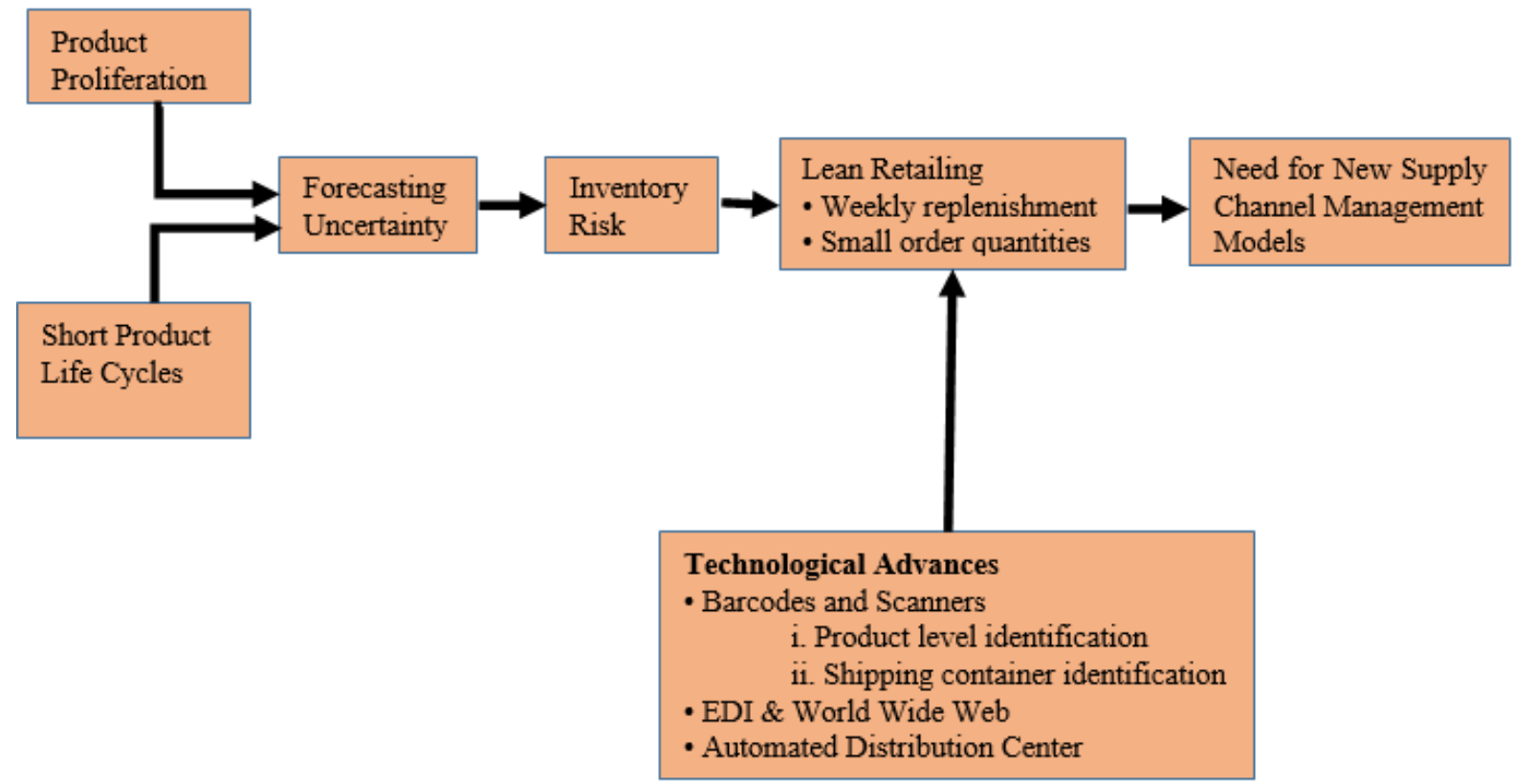

Figure 1. Forces driving lean retailing

Figure 2 depicts the channel associated with lean retailers, designed to lower the risk of delivering a plethora of apparel products to retail. (F. Abernathy, J. Dunlop, 1999). 


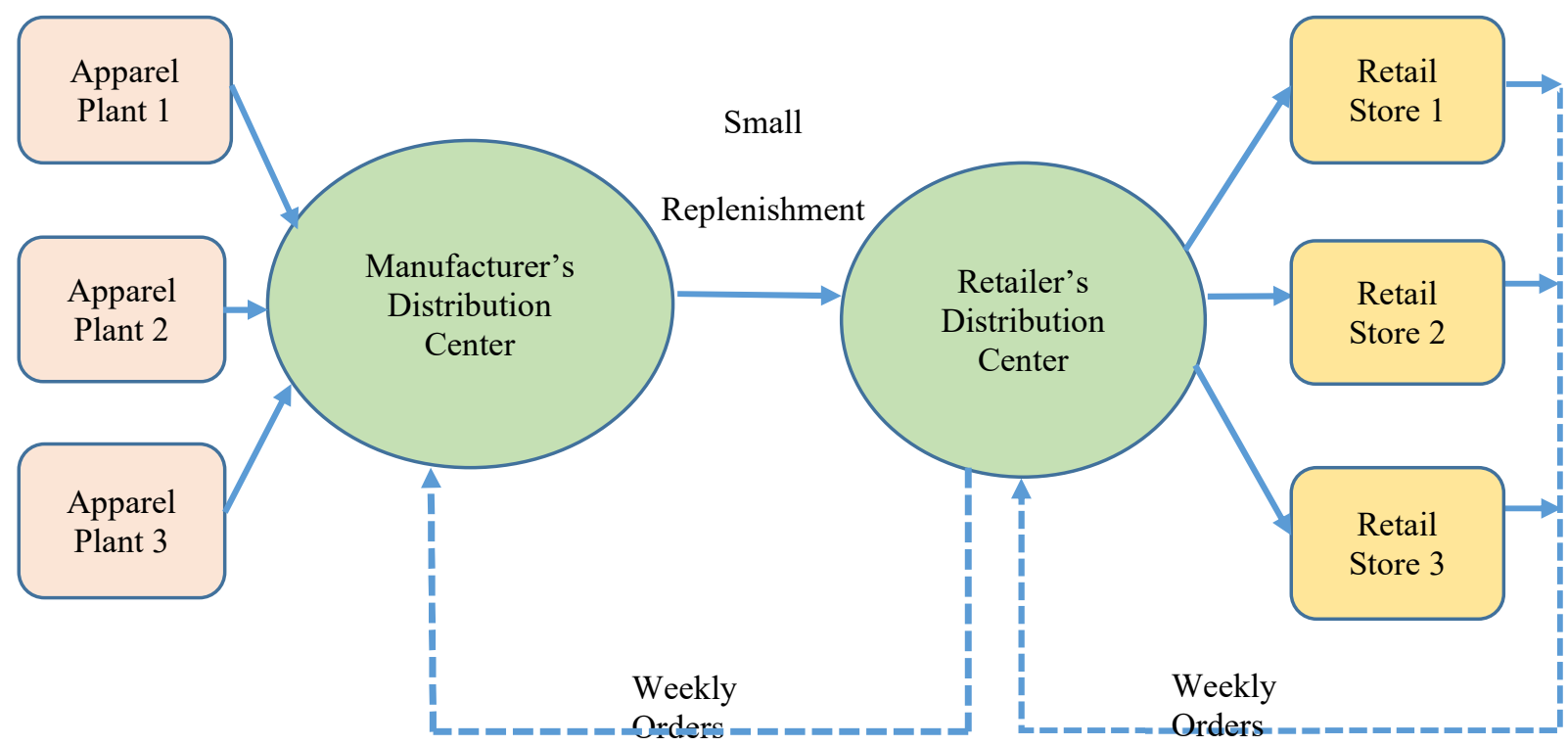

Figure 2. Channel Structure of Lean Retailer-Supplier Dynamics

\section{Success factors}

4.1 General Success factors

4.1.1 Globalization: The Company has taken initiatives to extend branches all over the world. The advertisement on international TV, newspaper, journals promoted the organization to establish business all over the world. The transparency of the clothing brand is another key factor to be globalized.

4.1.2 Competitive velocity: The organization carefully monitors the business strategy of its competitors, likeHennes and Mauritz (H\&M), Zara, Marks and Spencer (M\&S) etc. to add effective processes at clothing business.

4.1.3 A variety of fashionable quality wears: One of the early intentions of a high-end clothing store is to furnish the store with high-end fashionable dresses. UNIQLO maintains this with higher quality standards and by notable fashion designers (Hyde, Katherine, 2007).

4.1.4 Location agnostic: The location of the retail apparel shop is exceedingly important in the case of the clothing business. The place may be situated adjacent to a market, school, university etc. where people come frequently. All the retail stores of UNIQLO are situated close to public areas like - market, shopping mall (Hyde, Katherine, 2007).

4.1.5 Mutual beneficial supplier relationships: UNIQLO executives take care of the relationship between internal and external customers. The supplier is given a minimum lead time to supply products and they are paid regularly without provocation (Hyde, Katherine, 2007).

4.1.6 Effective store management and cleanliness: The customers come to visit the retail store, take a hand feel of merchandise and also monitor the decoration of the store. UNIQLO's retail stores are eye-catching, attractive, neat and clean that inspire customers to purchase the merchandise.

4.1.7 Smart sales person: Management of UNIQLO employs enthusiastic workers who want to build up their careers at merchandising apparel to target customers. They receive training from experts regularly as a part of their continuous improvement (White, Gillian B., 2019)

4.1.8 Continual improvement: Retail stores of UNIQLO very often add new fashionable items. Moreover, the authority hires innovative employees to improve the management system.

4.1.9 Target customers: It is indispensable for the clothing business to identify target customers. It helps to analyze the market like - to figure out what products are customers really looking for that retailer provides, what do they need and what are their expectations (Keller, K., 1993). People of all ages are the target customers of UNIQLO and they are discreet about their customers' comfort and fashion requirements.

4.1.10 ISO: 9001/14000 application: ISO: $9001 / 14000$ certification enhances the image of the store towards the customer. The customers do not think about wearing only rather they are sensible about the quality and ecosystem as well. Even they are also conscious about the maintenance of the garbage, recycling work etc. UNIQLO has recognition of ISO: 9001 and 14000 and they have an effective management system referring to the mentioned customers' concern (Hyde, Katherine, 2007).

4.1.11 Changing room/ Fitting room: UNIQLO's retail stores never overlook the influence of the fitting room experience of shoppers, and they realize that the fitting room actually impacts retail performance. The authority understands that well-furnished fitting rooms are small but mighty section of any retail store as they are one of the 
key components that contribute to the rise of sales and a decrease in returns. This is due to the fact that most purchasing decisions are carried out when shoppers like what they see in the fitting room (Hyde, Katherine, 2007). 4.1.12 Visual merchandising: Visual merchandising includes both store interior and exterior presentation. Physical attractiveness of the store impresses customers for store selection (Sinha, P.K. ,2004). Besides, UNIQLO use fascinated lighting treatment to draw the attention of customers (White, Gillian B., 2019).

4.1.13 Safety: In case of any mishap, fire or robbing, the retail stores of UNIQLO have a quick responding group to take effective actions.

\subsection{Critical Success Factors \\ i. $\quad$ Competitive Velocity (Yohn, D., 2016) \\ ii. A variety of wearing with standard quality and comfort. \\ iii. Location agnostic.}

\subsection{Measurable Process Measures}

4.3.1 Sales increase 15\% per year: An organization cannot go on without the enhanced sale every year because the expenditure of the company goes up gradually or steadily. For instance: salary increment, money inflation, taxes, business expansion etc. UNIQLO business is widening owing to its dynamic business strategy. It picks up the target to increase sales $15 \%$ per year (Hyde, Katherine, 2007).

4.3.2 Better customer service: If the customers are satisfied, they may come to purchase in the future. Therefore, UNIQLO has intelligent workers with an improved management system for customer care.

4.3.3 Customer satisfaction around 95\%: To sustain business at the competitive market UNIQLO always struggle to satisfy the customer as good as possible to get another order from him in the future. They provide their utmost endeavor to retain customer satisfaction level around 95\% (Hyde, Katherine, 2007).

4.3.4 Supplier Satisfaction $98 \%$ : It is a prerequisite to have quality raw materials from the supplier to make quality clothes for the customers. At this perspective, UNIQLO maintains a positive relationship with suppliers and try to provide supplier satisfaction level up to $98 \%$ (Hyde, Katherine, 2007).

4.3.5 Increase in innovation and technology by 5\% per year: UNIQLO has introduced ERP at its management system and current technology to intensify the production rate at least $5 \%$ than the preceding year. They still have a plan to import 3D visual merchandising at their retail stores in the near future. (Hyde, Katherine, 2007).

\section{BPM Model, Marketing Mix (4Ps), SWOT analysis and Porter's Five Forces Analysis}

Business Process Management (BPM) model is the graphical portrayal of a company's business workflows, as an aid of diagnosing likely improvements. BPM hands to have a deeper understanding of how processes work in addition to how the business operates. UNIQLO is capable to produce an amazing number of unique products because their business model brings together the entire clothes manufacturing process from planning and design through production, distribution, and retail. In addition, UNIQLO's market share is growing worldwide as it develops radical new materials simultaneously with the world's best fabric technology innovators and creates basic designs using superior natural ingredients. Furthermore, UNIQLO Life Wear is high-quality, innovative clothing that is comprehensive in construction and comfort hence it is made for everyone, everywhere. UNIQLO leverages today's increasingly digital world to interact directly with customers and immediately transform their desires into substantial products (White, Gillian B., 2019).

\subsection{Description of the BPM (Business Process Management) Model}

5.1.1 Management process: The administration department must be very strong. It is formed with- financial management, risk management, Marketing \& management plan, quality and environmental management.

5.1.2 Support process: The support process reinforces the management process to its function. For instancecleaning and surrounding management, human resource and supply management, marketing-advertisementinnovation and logistics (Banerjee, S.S., Bhushan, B., 2014).

5.1.3 Products: The product menus include T-shirts, jeans, casual wear,men-women' and kids' clothing, skirt, basic outfits, skirt outfits, casual outfits, hijab fashion etc. 


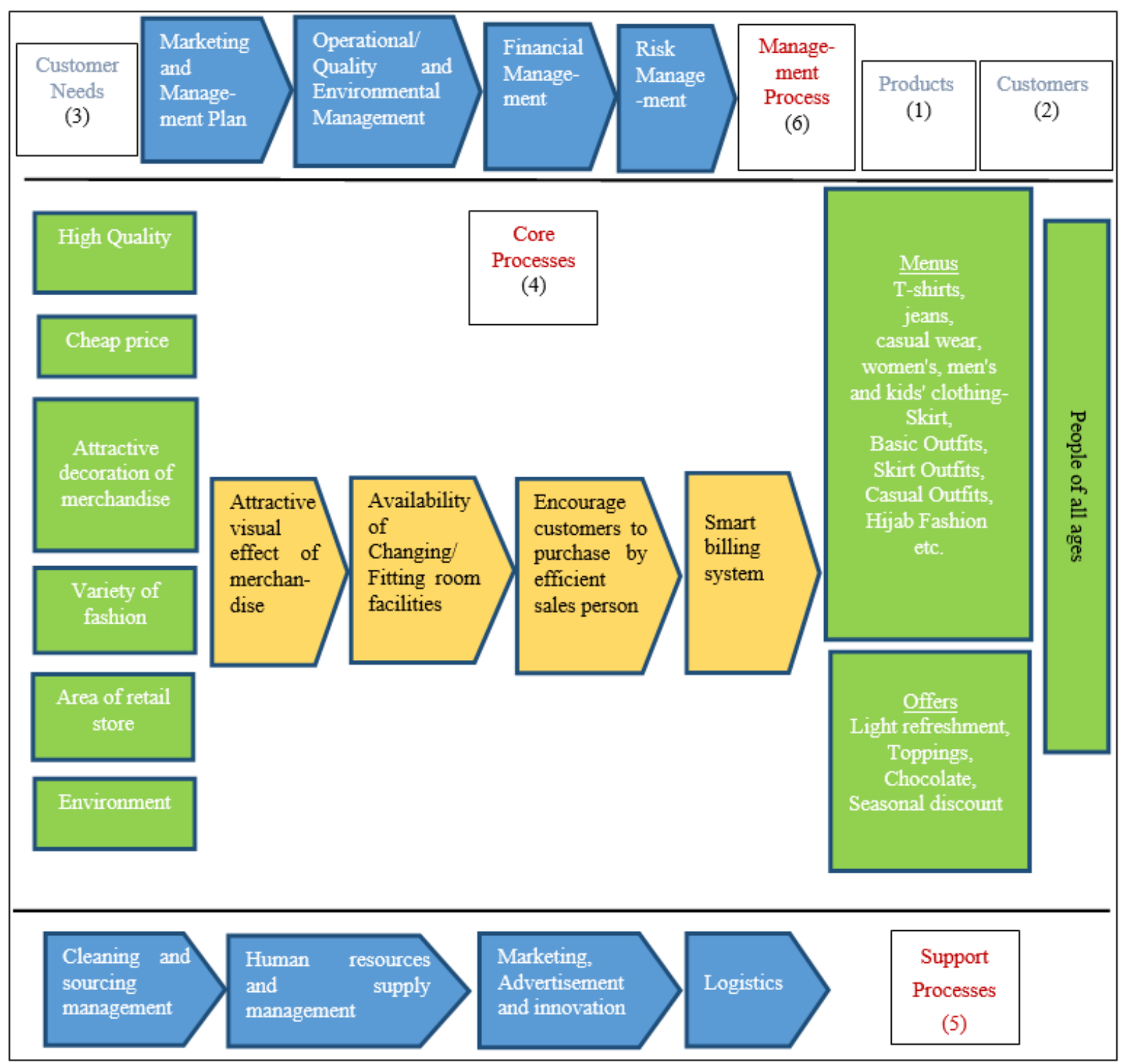

Figure 3. The BPM model

5.1.4 Core process: The core process involves attractive visual effect of merchandise, availability of changing/ fitting room facilities, convincing customers to purchase by efficient salesperson, smart billing system etc. 5.1.5 Customers: The targetted customers are the people of all ages.

\subsection{Marketing Mix (4Ps)}

McCarthy revealed that marketing management consists of - creating or developing a product (Product), determining the price (Price), practicing promotions (Promotion) and set up a distribution place activity (Place) (2010). 
Table 1. Marketing Mix (4Ps)

\begin{tabular}{|c|c|}
\hline Product & Price \\
\hline $\begin{array}{l}\text { UNIQLO's strength relies on its updated variety, product } \\
\text { designs and appropriate pricing with its simple, elegant, and } \\
\text { wise quality products in affordable cost, but its fundamental } \\
\text { strength relies on its comfort and well-patterned products. Its } \\
\text { carrier bag could be used as a form of walking advertising } \\
\text { (Posner, Harriet, 2011). }\end{array}$ & $\begin{array}{l}\text { The interview results that the pricing of } \\
\text { UNIQLO's product is determined by adopting } \\
\text { the 'Realistic Selling Price' approach. }\end{array}$ \\
\hline $\begin{array}{l}\text { Place } \\
\end{array}$ & Promotion \\
\hline $\begin{array}{l}\text { Many respondents still prefer shopping from the retail store. } \\
\text { Some of them felt that online shopping is convenient because } \\
\text { it is quite crucial for them to make time to shop from the retail } \\
\text { store. UNIQLO's fashion experts offer a win-win solution } \\
\text { that their products will be marketed both offline through } \\
\text { consignment and online through a web store purchase. }\end{array}$ & $\begin{array}{l}\text { UNIQLO's retail stores rely on window display } \\
\text { and visual merchandising for their promotion. } \\
\text { Again for online selling, two executives shared } \\
\text { that they will take initiative for celebrity } \\
\text { endorsement and celebrity seeding promotion } \\
\text { technique. Price reduction and discount offers } \\
\text { are also a valuable means of sales promotion } \\
\text { because local consumers are cost-sensitive. }\end{array}$ \\
\hline
\end{tabular}

\subsection{SWOT Analysis}

SWOT explains about the internal and external condition that applies strategic planning for the business. Following SWOT analysis is presented focusing on the UNIQLO brand to launch a new retail shop.

Table 2. SWOT Analysis

\begin{tabular}{|c|c|c|}
\hline \multicolumn{2}{|r|}{ Strength } & Weakness \\
\hline i. & Unique design & High transportation cost \\
\hline ii. & Availability of raw materials & Language barrier \\
\hline iii. & Many category products to offer & Lack of some amenities to digitalize retail \\
\hline iv. & Easy to wear and more accessible to buyer & stores. \\
\hline v. & Brand reputation & \\
\hline \multicolumn{2}{|r|}{ Opportunity } & Threats \\
\hline i. & Expand the fashion business in Bangladesh & Risk of new product category \\
\hline ii. & Attractive market & Inflation \\
\hline iii. & $\begin{array}{l}\text { Give a chance to online store getting closer } \\
\text { to their loyal customer. }\end{array}$ & Risk of new comers \\
\hline
\end{tabular}

\subsection{Porter's Five Forces Analysis}

The purpose of Porter's Five Forces analysis is to interpret the strategic implications for an individual company within a market (Dobbs, M. E., 2014) 


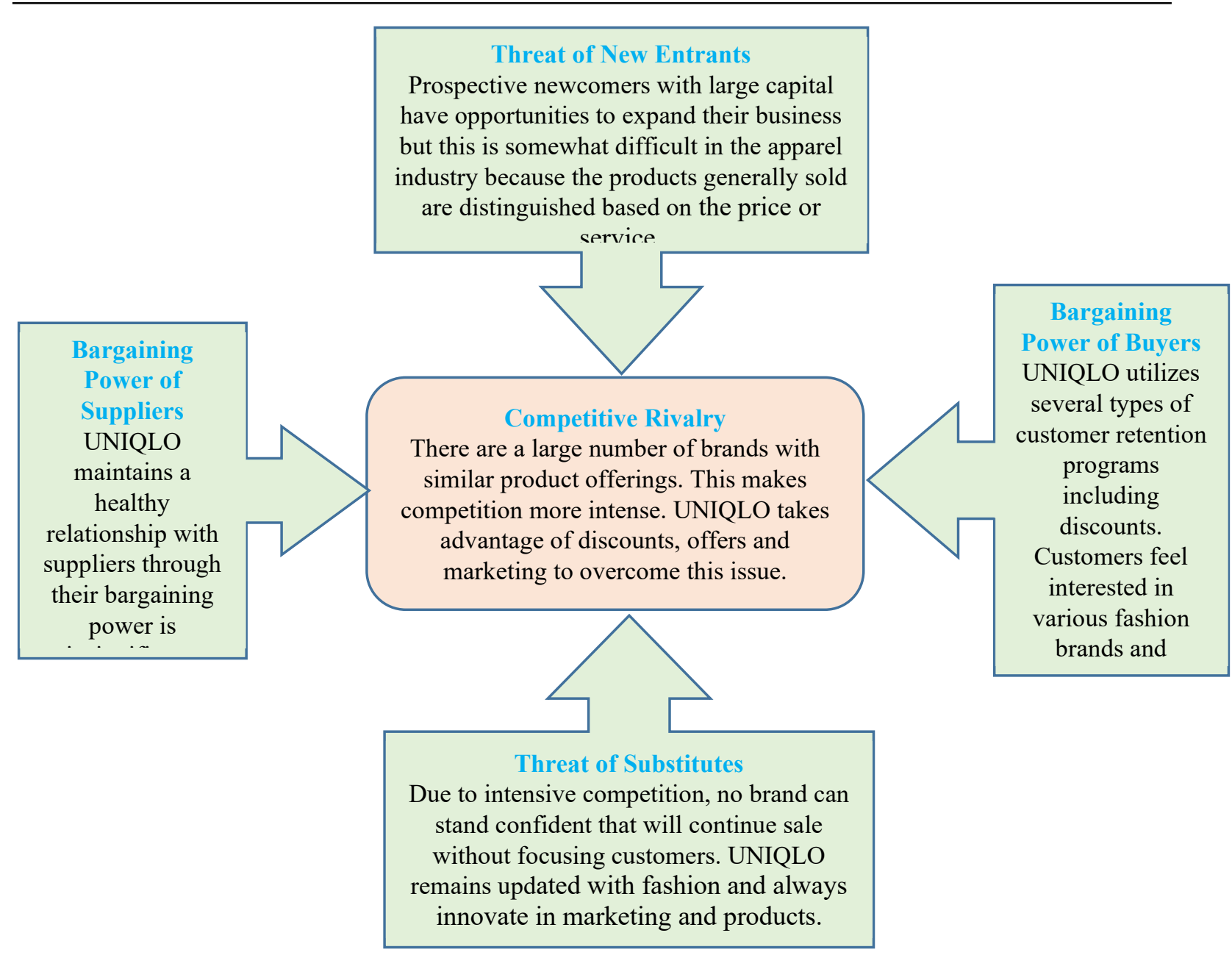

Figure 4. Porter's Five Forces Model

\section{Discussion, Findings and Results \\ 6.1 Discussion}

The The BPM model is most essential for entrepreneurs with a view to getting the idea instantly to initiate a retail clothing business. The proposed retail store will serve the best quality service to the customers at competitive prices with a viable business. Recycling the used commodities, reusing the products and reducing the use of the products do not harm the environment. As the organization will work to improve continuously (to become the number one fashion brand), they will add different tools in the process to build the images around the world, for instance- the 3 R's, ISO 9001/14000, ERP. The ERP system is required to support efficient information flow around the whole organization. It will also facilitate to ensure good Supply and Demand Chain Management (SDCM). As the customers not only consider quality clothing at a cheap price but also look for sustainability therefore the ISO certification is required. The retail shop requires efficient salespersons to sell wearings to targeted customers. In addition, the retail store will build high-quality changing/ fitting rooms and decent environment to attract the potential customers. Moreover, the retail stores should be situated around the busy places of a municipality to get more customers. It is required to follow the competitors of the company around the world to change or improve the total system additionally mentors can be hired to install new fashion, design or modern systems. The company has to train the employees at a periodic interval to gain effective service from them.

\subsection{Findings and Results}

From the overmentioned clarification, it can be inferred that the business and marketing strategy of UNIQLO was benchmarked with the support of the BPM model. Firstly, it introduces the message about the required wearing and fashion trend of the customers. Secondly, it discusses the supervision process of the retail outlet, in the same way, the support process. Thirdly, it shows the root process of receiving the order to trade. At last, it elaborates on the menus of the wearings to sell at the retail shop and the targetted customers of all ages. SWOT analysis, Marketing Mix and Porer's five forces analysis are auxiliary but essential tools to develop its business and marketing strategy. An apparel business entrepreneur will definitely be able to know about the required steps, 
challenges, channels, business and marketing strategy to start up a new apparel retail store from this study.

\section{Conclusion}

BPM is one of the strongest tools to get a deep insight into an organization's processes and its working procedure for each department. It pushes to implement SMART act within the institution. Moreover, it is a successful medium for supply and demand chain management. From SWOT we can find out the strength, weaknesses, threats and feasible opportunities for determining the company's stand at the market. By Porter's Five Forces model, it is flexible to perceive the condition of the entire organization, customers and opponents. Finally, it is settled that a lean retailing or order-driven technique is the most convenient option to avoid bull-whip effect for inaugurating a new apparel retail store.

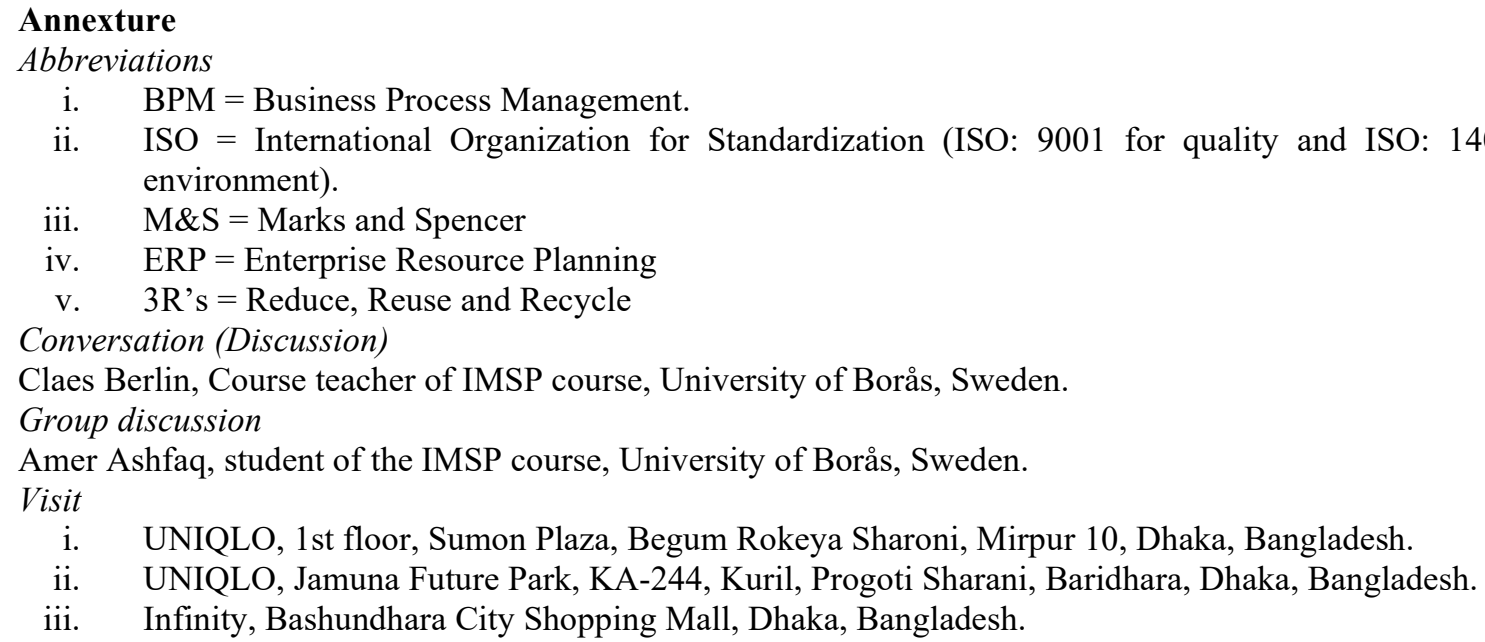

\section{References}

Baker, J., Grewal, D. \& Levy (1992), A.T. Kearney's Global Retail Development Index: An experimental approach to making retail store environmental decisions, Journal of Retailing (68) 445-460.

Banerjee, S.S., Bhushan, B., Retail Sales Mix: A Conceptual Framework to Model Building.

Bryman, A. \& Bell, E. (2007) Business Research Methods. Oxford University Press.

Burt, S. and Carralero-Encinas, J. (2000) the role of store image in retail internationalization. International Marketing Review 17:4-5, pp. 433-453. Business Review.

Dobbs, M. E. (2014). Guidelines for applying Porter's five forces framework: a set of industry analysis templates. Competitiveness Review An International Business, 24 (1), 32-45.

F. Abernathy, J. Dunlop, J. Hammond and D. Weil, Oxford University Press, 1999.Lean Retailing and the future of Manufacturing: Lessons from the Textile and Apparel Industries.

Hadiwidjojo, J. Y., \& Bernardus, D. (2016). The Planning of the 4PS Marketing Strategy in Apparel Brand Ahimsa. Harriet, Posner (2011). Marketing Fashion. 1. vydání.

Hasan, M., Issar, A., Ojha, G., \& Singh, B. P. (2006, November 6). Indian retail: the Indian retail bazaar.Brand Strategy, p.36.

Hawkins, Del I. \& Tull, Donald S., (2004), Marketing Research in Practice, Marketing Research-Measurement and Method, 6th edition, pp 1-4.

Hyde, Katherine (26 April 2007). "UNIQLO: From Tokyo to New York to Global Brand". Japan Society. Retrieved 22 December, 2012.

Keller, K. (1993) Conceptualizing, Measuring, Managing Customer-Based Brand Equity. Journal of Marketing, 57(1): 1-22

Kotler, P., Armstrong, G., Wong, V. \& Saunders, J. (2008) Marketing defined: Principles of Marketing. Harlow : Pearson Education.

Kotler, Philip, \& Amstrong, Gary. (2013). Principles of Marketing 15e. USA: Pearson Prentice Hall.

Kumar, I., Garg, Ruchi\& Rahman, Zillur (2010), Influence of retail atmospherics on customer value in an emerging market condition, Great Lakes Herald, Vol-4, No-1, 1-13.

Sinha, P.K. (2004), Store choice behaviour in an evolving market, International Journal of Retail and Distribution Management, 32(10), 482-496.

Slaton, K., Testa, D., Bakhshian, S., Reid, S., and Fiore, A. M., "The New Face of Retailing: The Impact of the Small, Inventory-Free Store Experience on Brand Equity and Ordering Behavior" (2018). International Textile and Apparel Association (ITAA) Annual Conference Proceedings. 84. 
Slaton, Kelcie; Testa, Danielle; Bakhshian, Sonia; Reid, Shantell; and Fiore, Ann Marie, "The New Face of Retailing: The Impact of the Small, Inventory-Free Store Experience on Brand Equity and Ordering Behavior" (2018). International Textile and Apparel Association (ITAA) Annual Conference Proceedings. 84.

White, Gillian B. (13 March 2019). "Why Urban Millennials Love UNIQLO". The Atlantic. Retrieved 14 March, 2019.

Wolfe, Mary. (2009). Fashion Marketing \& Merchandising. USA: The Goodheart-Willcox Company, Inc.

Yohn, D. (2016, June). Big-box retailers have two options if they want to survive. Harvard University.

\section{Authors Profile}

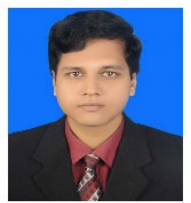

Taposh Ranjan Sarker is currently working as a Lecturer at the Department of Textile Engineering, Northern University Bangladesh. He completed his M.Sc. (Thesis) in Textile Engineering from Bangladesh University of Textiles. He has also completed his MBA from Bangladesh University of Professionals furthermore awarded vice chancellor's gold medal in 2019.

Lefayet Sultan Lipol has been working as a teacher since 2007. He is working as Assistant Professor and Head at the Department of Textile Engineering, Northern University Bangladesh. He was a former Research assistant in SP Technical Research Institute of Sweden. He completed his M.Sc. in Textile Engineering from University of Boras, Sweden.

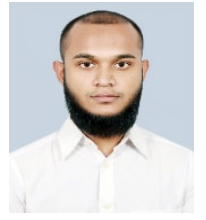

Abdullah Al Saeed is currently working as a Lecturer in Mechanical Engineering at the Department of Textile Engineering in Northern University Bangladesh. He completed his B.Sc. in Mechanical Engineering from Islamic University of Technology in 2016. 